\title{
$C D_{8+} T$ lymphocytes in lung tissue from patients with idiopathic pulmonary fibrosis
}

\author{
Zoe Daniil ${ }^{1}$, Panagiota Kitsanta ${ }^{2}$, George Kapotsis ${ }^{1}$, Maria Mathioudaki², \\ Androniki Kollintzaㄹ, Marilena Karatza ${ }^{3}$, Joseph Milic-Emili4, \\ Charis Roussos ${ }^{1}$ and Spyros A Papiris*1
}

Address: ${ }^{1}$ Department of Critical Care and Pulmonary Services, National and Capodistrian University of Athens, "Evangelismos" Hospital, Athens, Greece, 2 Pathology Department, "Evangelismos" Hospital, Athens, Greece, ${ }^{3}$ Hematology Department, "Evangelismos" Hospital, Athens, Greece and ${ }^{4}$ Meakins-Cristie Laboratories, McGill University, Montreal, Quebec, Canada

Email: Zoe Daniil - zdaniil@med.uth.gr; Panagiota Kitsanta - Panagiota.Kitsanta@sth.nhs.uk; George Kapotsis - gkapotsis@hotmail.com; Maria Mathioudaki - mmathioudaki@hotmail.com; Androniki Kollintza - akollin@hotmail.com; Marilena Karatza - mkaratza@otenet.gr; Joseph Milic-Emili - Joseph.Milic-Emily@mcgill.ca; Charis Roussos - Croussos@med.uoa.gr; Spyros A Papiris* - papiris@otenet.gr

* Corresponding author

Published: 24 July 2005

Respiratory Research 2005, 6:8I doi:I0.1186/|465-992I-6-8I

This article is available from: http://respiratory-research.com/content/6/I/8

(c) 2005 Daniil et al; licensee BioMed Central Ltd.

This is an Open Access article distributed under the terms of the Creative Commons Attribution License (http://creativecommons.org/licenses/by/2.0), which permits unrestricted use, distribution, and reproduction in any medium, provided the original work is properly cited.

\begin{abstract}
Background: Several studies have implicated a role of inflammation in the pathogenesis of lung damage in idiopathic pulmonary fibrosis (IPF). Parenchymal lung damage leads to defects in mechanics and gas exchange and clinically manifests with exertional dyspnea. Investigations of inflammatory cells in IPF have shown that eosinophils, neutrophils and $\mathrm{CD}_{8+}$ TLs may be associated with worse prognosis. We wished to investigate by quantitative immunohistochemistry infiltrating macrophages, neutrophils and T lymphocytes (TLs) subpopulations $\left(\mathrm{CD}_{3_{+}}, \mathrm{CD}_{4_{+}}\right.$and $\left.\mathrm{CD}_{8_{+}}\right)$in lung tissue of patients with IPF and their correlation with lung function indices and grade of dyspnoea.
\end{abstract}

Methods: Surgical biopsies of 12 patients with IPF were immunohistochemically stained with mouse monoclonal antibodies (anti- $C D_{68}$ for macrophages, anti-elastase for neutrophils, and anti- $C D_{3}$, anti- $C D_{4}$, anti- $C D_{8}$ for $C D_{3+} T L s$, $C D_{4+} T L s$, and $C D_{8+} T L s$ respectively). The number of positively stained cells was determined by observer-interactive computerized image analysis (SAMBA microscopic image processor). Cell numbers were expressed in percentage of immunopositive nuclear surface in relation to the total nuclear surface of infiltrative cells within the tissue (labeling Index). Correlations were performed between cell numbers and physiological indices [FEV, FVC, TLC, DLCO, $\mathrm{PaO}_{2}, \mathrm{PaCO}_{2}$ and $\left.\mathrm{P}(\mathrm{A}-\mathrm{a}) \mathrm{O}_{2}\right)$ ] as well as dyspnoea scores assessed by the Medical Research Council (MRC) scale.

Results: Elastase positive cells accounted for the $7.04 \% \pm 1.1$ of total cells, $C D_{68+}$ cells for the $16.6 \% \pm 2, C_{3+} T L s$ for the $28.8 \% \pm 7, C D_{4+}$ TLs for the $14.5 \pm 4$ and $C_{8+}$ TLs for the $13.8 \pm 4 . C_{8+}$ TLs correlated inversely with FVC \% predicted $\left(r_{s}=-0.67, p=0.01\right)$, TLC \% predicted $\left(r_{s}=-0.68, p=0.01\right)$, DLCO \% predicted $\left(r_{s}=-0.6 \mathrm{I}, \mathrm{p}=0.04\right)$, and $\mathrm{PaO}_{2}\left(r_{\mathrm{s}}=-0.60, \mathrm{p}=0.04\right)$. Positive correlations were found between $\mathrm{CD}_{8+} \mathrm{TLs}$ and $\mathrm{P}(\mathrm{A}-\mathrm{a}) \mathrm{O}_{2}\left(r_{\mathrm{s}}=0.65, \mathrm{p}=0.02\right)$ and $C D_{8+}$ TLs and MRC score $\left(r_{s}=0.63, p=0.02\right)$. Additionally, $C D_{68+}$ cells presented negative correlations with both FVC $\%$ predicted $\left(r_{s}=-0.80, p=0.002\right)$ and $F E V, \%$ predicted $\left(r_{s}=-0.68, p=0.01\right)$.

Conclusion: In UIP/IPF tissue infiltrating mononuclear cells and especially $\mathrm{CD}_{8+}$ TLs are associated with the grade of dyspnoea and functional parameters of disease severity implicating that they might play a role in its pathogenesis. 


\section{Background}

In usual interstitial pneumonia (UIP)/idiopathic pulmonary fibrosis (IPF) the role of inflammation in the pathogenesis of fibrosis is debatable [1-3]. Traditionally, UIP/ IPF was regarded to develop in response to chronic inflammation of the lung parenchyma [4]. This view was advanced from previous studies implicating a role of the inflammatory cells including neutrophils, macrophages, eosinophils and Tlymphocytes (TLs), based on the observation of their accumulation in sites of disease activity [58 ] or on their presence in high numbers in bronchoalveolar lavage [9-12].

Actually, the current pathogenetic theory that holds in UIP/IPF, implicates that fibrosis per se might progress despite a paucity of interstitial inflammation [13]. However, even in this case, recent data still indicate the contention that the type of the inflammatory response may modulate tissue injury, fibrosis or both $[3,4]$. Animal studies imply that TLs might play a role in the initiation and the evolution of pulmonary fibrosis. They also suggest that different TLs subpopulations, including both $\mathrm{CD}_{4+}$ and $\mathrm{CD}_{8+}$ subsets, might contribute through their ability to secrete fibrogenic cytokines [14,15]. Ultimately, in UIP/IPF, the inflammatory response is considered to resemble closely the type-2 T lymphocytic pattern [16-18] and drives the process in a profibrogenic direction.

The present study was designed to investigate by quantitative immunohistochemistry the inflammatory cell pattern in lung tissue of patients with UIP/IPF (macrophages, neutrophils, and $\mathrm{CD}_{3+}, \mathrm{CD}_{4+}, \mathrm{CD}_{8+}$ TLs) and to correlate their population numbers with the lung function indices and grade of dyspnoea.

\section{Methods \\ I. Subjects}

The study population consisted of 12 untreated patients with IPF and included 7 ex-smokers, and 5 never smokers (Table 1). They were recruited from the respiratory outpatient clinic of the "Evangelismos" General Hospital, Athens, Greece over a period of 3 years. The diagnosis of UIP/ IPF was based on standard criteria [19], which included clinical findings (exertional dyspnoea, non-productive cough, fine bibasilar inspiratory crackles), pulmonary function tests (restrictive pattern and impaired gas exchange), and high resolution computerized tomography findings (bibasilar reticular abnormalities with minimal ground-glass opacities consistent with the diagnosis of IPF). The diagnosis of UIP/IPF was confirmed by videoassisted thoracoscopic lung biopsy in all patients. Pathology examination of these specimens clearly documented UIP according to Katzenstein's and American Thoracic Society - European Respiratory Society criteria (histologic variation with alternating zones of interstitial fibrosis,
Table I: Demographic, clinical and lung function data of all patients at presentation

\begin{tabular}{ll}
\hline Variables & Values \\
\hline Age (yr) & $60 \pm 2$ \\
Sex (M/F) & $5 / 7$ \\
$M R C$ dyspnoea score & $1.8 \pm 0.3$ \\
$\mathrm{FEV}(\% \mathrm{pr})$ & $85 \pm 4$ \\
$\mathrm{FVC}(\% \mathrm{pr})$ & $78 \pm 4$ \\
$\mathrm{FEV} / \mathrm{FVC}($ ratio $\times 100)$ & $85 \pm 4$ \\
$\mathrm{TLC}(\% \mathrm{pr})$ & $64 \pm 3$ \\
$\mathrm{RV}(\% \mathrm{pr})$ & $54 \pm 4$ \\
$\mathrm{DLCO}(\% \mathrm{pr})$ & $50 \pm 5$ \\
$\mathrm{PaO}(\mathrm{mmHg})$ & $75 \pm 2$ \\
$\mathrm{P}(\mathrm{A}-\mathrm{a}) \mathrm{O}_{2}$ & $30 \pm 3$ \\
$\mathrm{PaCO}_{2}(\mathrm{mmHg})$ & $36 \pm 3$ \\
\hline
\end{tabular}

Data are presented as means $\pm \mathrm{SEM} ; \mathrm{M}=$ Male; $\mathrm{F}=$ Female; $p r$ : predicted

inflammation, honeycomb change, and normal lung $[1,19]$. A right thoracic approach was done and two or three samples were taken from the right lower or middle lobe in the region of the greater fissure. Biopsy of the lingular tip was avoided, as changes in this area may be particularly advanced and unrepresentative. All patients experienced a normal and uncomplicated postoperative course. Secondary causes of lung fibrosis were excluded: none of the patients included in this study had a history of environmental or occupational exposure, drug toxicity or connective tissue disease, as documented by patient's history and thorough clinical and immunological work out. The study was approved by the institutional ethics committee and informed consent was obtained from each patient.

\section{Pulmonary function tests}

The pulmonary function tests included $\mathrm{FEV}_{1}, \mathrm{FVC}_{1} \mathrm{FEV}_{1} /$ FVC ratio $\times 100$, total lung capacity (TLC), residual volume (RV) and carbon monoxide transfer factor (DLCO). TLC and RV were measured by the helium dilution method with a Master Screen apparatus (Erich Jaeger GmbH, Wuerzburg, Germany), and DLCO by the single breathholding helium dilution method [20,21]. Lung function measurements (Table 1) were expressed as percentages of predicted values $[20,21]$. In all patients, the arterial $\mathrm{PaO}_{2}$ and $\mathrm{PaCO}_{2}$ were also measured at rest, and $\mathrm{P}(\mathrm{A}-\mathrm{a}) \mathrm{O}_{2}$ calculated.

\section{Dyspnea}

Dyspnea was assessed with the modified (6-point) MRC dyspnoea self-administered questionnaire [22] that consists of six questions about perceived breathlessness: category 0 , no dyspnoea; category 1 , slight degree of dyspnoea (troubled by shortness of breath when hurrying on the 
level or walking up a slight hill); category 2, moderate degree of dyspnoea (walks slower than people of the same age on the level because of breathlessness); category 3, moderately severe degree of dyspnoea (has to stop because of breathlessness when walking at own pace on the level); category 4, severe degree of dyspnoea (stops for breath after walking about 100 yards or after a few minutes on the level); category 5, very severe degree of dyspnoea (too breathless to leave the house or breathless when dressing or undressing).

\section{Histology}

Open lung biopsies from the 12 patients were used. They were taken for diagnostic and staging purposes and were analyzed according to the Katzenstein's criteria [1] by two pathologists. Specimens were fixed in $4 \%$ formalin and after dehydration embedded in paraffin. Tissue sections were orientated and serial sections of $4 \mu \mathrm{m}$ thickness were cut and immunohistochemistry was performed according to the Streptavidin-Biotin method.

\section{Immunohistochemistry}

To evaluate macrophages, neutrophils and the lymphocyte-subpopulations in lung tissues, $4 \mu \mathrm{m}$ paraffin sections were immunohistochemically stained with the following mouse monoclonal antibodies (all from DAKO, Glostrup, Denmark): macrophages-histiocytes with anti $\mathrm{CD}_{68}$, (clone: M814, dilution 1:4000), neutrophils with anti-elastase (clone:M752 dilution 1:4000), T-cells with anti- $\mathrm{CD}_{3}$ (dilution 1:200), anti- $\mathrm{CD}_{4}$ (dilution $1: 100$ ), and anti- $\mathrm{CD}_{8}$ (dilution 1:4), according to the labeled Streptavidin-Biotin Complex method. The sections were deparaffinized and rehydrated with Tris-Buffered Saline (TBS: $0.005 \mathrm{M}$ Tris, $0.15 \mathrm{M} \mathrm{NaCl}$ ), $\mathrm{pH}=7.6$ for 10 minutes. Endogenous peroxidase was blocked with 3\% hydrogen peroxide for 5 minutes. Then they were washed in TBS and incubated with primary antibodies at the appropriate dilutions for one hour. Biotinylated antimouse IgG was used as a secondary antibody (DAKO), followed by peroxidase-conjugated streptavidin (DAKO). The peroxidase reaction was developed using 3,3'-diaminbenzidine tetrachloride $(0.25 \mathrm{mg}$ dissolved in $1 \mathrm{ml}$ of $0.02 \%$ hydrogen peroxide) for $3 \mathrm{~min}$.

\section{Lung Parenchyma Computer Image Analysis}

The number of positively stained cells was determined by observer-interactive computerized image analysis (SAMBA microscopic image processor), whose hardware and software have been described by Brugal and associates [23]. This system is fitted with a standard Zeiss axioplan microscope, a color video camera (Sony Corporation Tokyo, Japan), an image analysis processor (matrox) and an IBM compatible Pentium 2, 166 MHZ computer. Estimation of the standard error of the mean within $95 \%$ confidence limits required a maximum of at least randomly selected 15 High Power fields (X400-Zeiss microscope) (Analysis per area of approximately $110000 \mu \mathrm{m}^{2}$ ). The immunostaining was analyzed as dark brown color with counterstained cells as false blue. Formal scoring (labeling Index) for each antibody was then performed in one section for each paraffin block. Interobserver variability was very low $(<0.03 \%)$. The results were expressed in percentage of immunopositive nuclear surface in relation to the total nuclear surface of infiltrative cells within the tissue (labeling Index), as previously described [24,25]. Blood vessels, connective tissue and cartilage structures were excluded.

\section{Statistical Analysis}

Data were expressed as means and standard error (SEM). Correlation coefficients were calculated using Spearman's rank method. A p-value of less than 0.05 was considered statistically significant. Analysis was performed using the SAS System software.

\section{Results}

Demographic characteristics, MRC dyspnoea score and lung function data of all patients are listed in Table 1. All patients claimed some degree of dyspnoea (MRC score > 0 ) and most patients had a restrictive lung function pattern characterized by a decrease in TLC (mean value was $64 \%$ of predicted) and an increased in $\mathrm{FEV}_{1} / \mathrm{FVC}$ ratio $\times 100$ (mean value was $85 \%$ of predicted). The DLCO was decreased in all patients (mean value was $50 \%$ of predicted).

Among the inflammatory cells studied $\mathrm{T}$ lymphocytes $\left(\mathrm{CD}_{3+}\right)$ appeared as the most numerous cells infiltrating the lung parenchyma. They were found in aggregates, within lymphoid follicles or diffusely within the fibrotic lung parenchyma and mainly in the areas with moderate or severe thickening of the alveolar wall. They were also observed within the wall of the alveoli. The $\mathrm{CD}_{4+}$ subpopulation was found in aggregates inside or around lymphoid follicles. A little portion of them infiltrated the lung parenchyma diffusely, especially the alveolar wall. On the other hand, the $\mathrm{CD}_{8+}$ cells infiltrated the parenchyma mainly diffusely (Fig 1); they were also found within the alveolar wall, around the fibrotic foci and in the areas with alveolar thickening. Less commonly they were distributed within aggregates or lymphoid follicles. Macrophages $\left(\mathrm{CD}_{68+}\right.$ cells) were preferentially located in the lamina propria of the airways compared with the surface epithelium and the submucosa. They were also distributed in large aggregates in the dilated alveolar spaces. Neutrophils (Elastase+) were mainly observed in the surface epithelium and within the alveolar wall.

Elastase positive cells accounted for the $7.04 \% \pm 1.1$ of total cells, $\mathrm{CD}_{68+}$ cells for the $16.6 \% \pm 2, \mathrm{CD}_{3+}$ TLs for the 


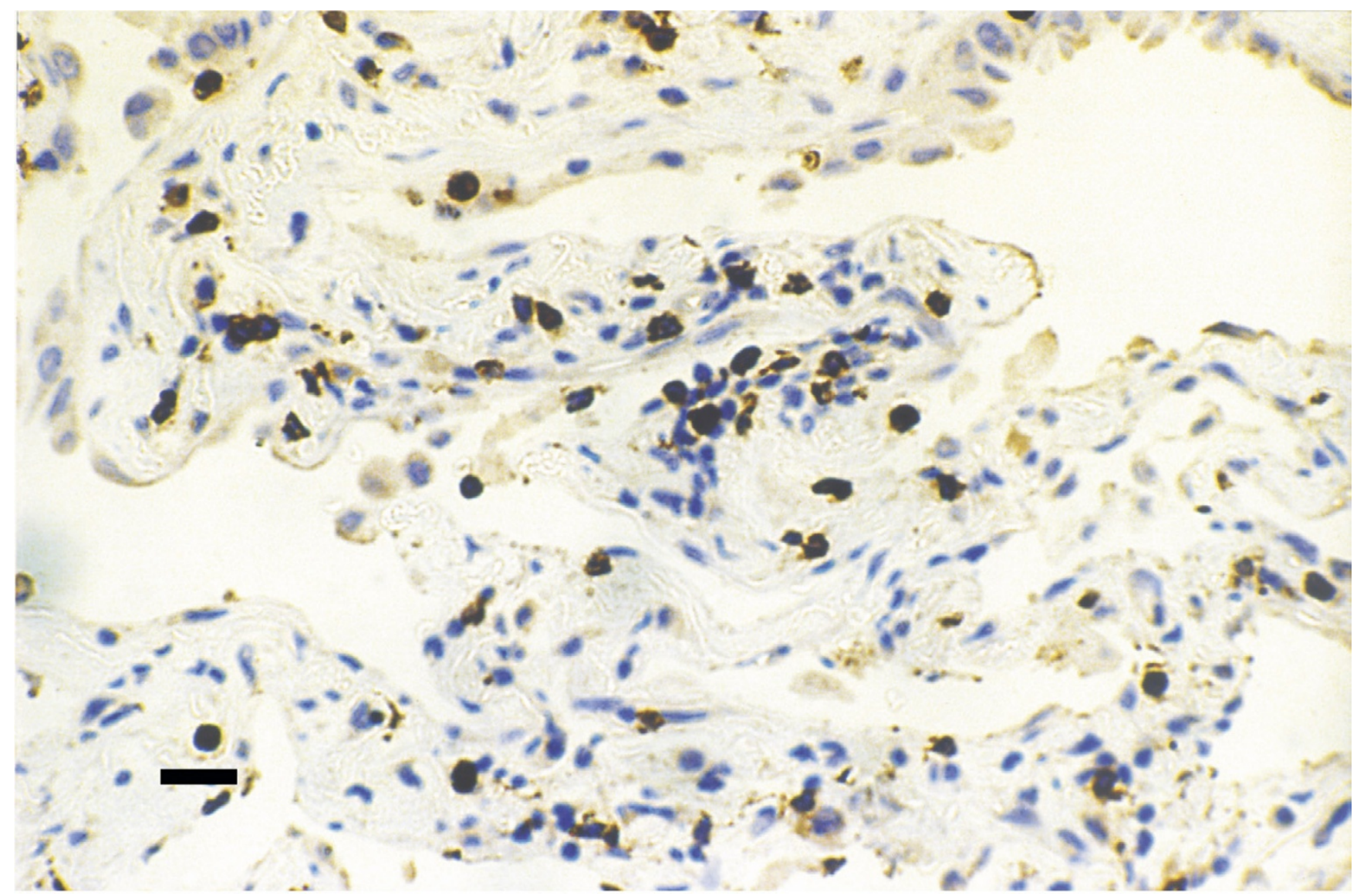

Figure I

The $C D_{8+} T L s$ infiltrate diffusely the lung parenchyma (scale bar $=25 \mu \mathrm{m}$ ).

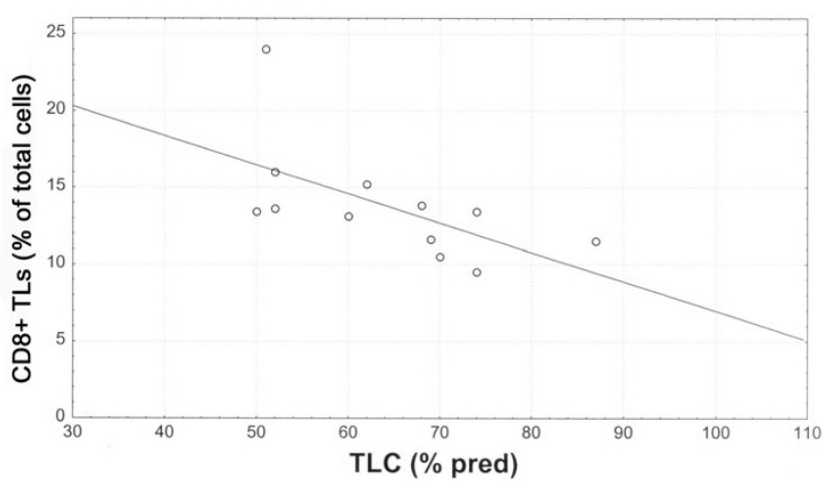

Figure 3

Relationship between $\mathrm{CD}_{8+} \mathrm{TLs}$ (\% of total cells) and TLC (\% predicted), $\left(r_{s}=-0.68, p=0.01\right)$.
$28.8 \% \pm 7, \mathrm{CD}_{4+}$ TLs for the $14.5 \pm 4$ and $\mathrm{CD}_{8+}$ TLs for the $13.8 \pm 4$. Among the infiltrating inflammatory cells, $\mathrm{CD}_{8+}$ TLs were inversely correlated with FVC \% predicted $\left(r_{s}=-0.67, p=0.01\right)($ Fig 2$)$, TLC $\%$ predicted $\left(r_{s}=-0.68\right.$, $\mathrm{p}=0.01)($ Fig 3$), D L C O \%$ predicted $\left(\mathrm{r}_{\mathrm{s}}=-0.61, \mathrm{p}=0.04\right)$, $\mathrm{PaO}_{2}\left(\mathrm{r}_{\mathrm{s}}=-0.60, \mathrm{p}=0.04\right)$. Positive and statistically significant correlations were found between $\mathrm{CD}_{8+}$ TLs and $\mathrm{P}(\mathrm{A}$ a) $\mathrm{O}_{2}\left(\mathrm{r}_{\mathrm{s}}=0.65, \mathrm{p}=0.02\right)$ and $\mathrm{CD}_{8+}$ TLs and MRC score $\left(\mathrm{r}_{\mathrm{s}}\right.$ $=0.63, \mathrm{p}=0.02)$ (Fig 4). Additionally, the $\mathrm{CD}_{68+}$ cells presented significant negative correlations with the FVC \% predicted $\left(\mathrm{r}_{\mathrm{s}}=-0.80, \mathrm{p}=0.002\right)$ and the $\mathrm{FEV}_{1} \%$ predicted $\left(r_{s}=-0.68, p=0.01\right)$. Elastase positive cells, $C_{3+}$ TLs, and the $\mathrm{CD}_{4+}$ TLs did not correlate with any of the functional indices as well as the MRC score.

\section{Discussion}

Several studies have implicated a role of inflammation in the pathogenesis of lung damage in IPF. Parenchymal lung damage leads to defects in mechanics and gas exchange and consequently to exertional dyspnoea, the 


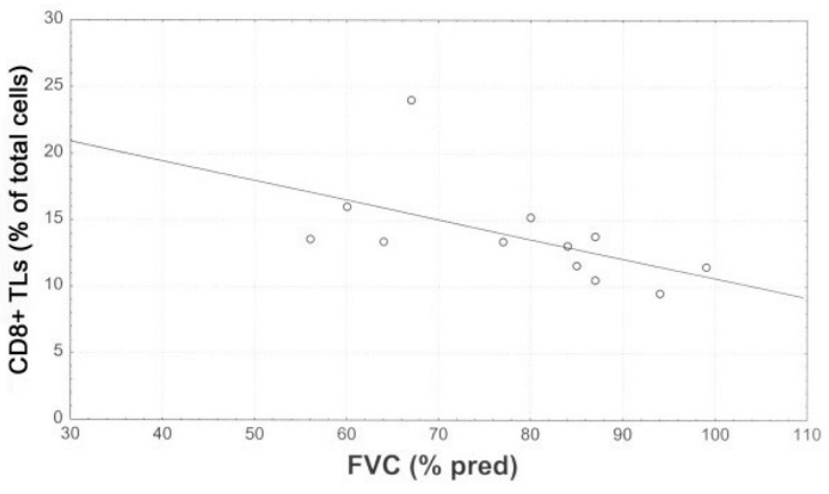

\section{Figure 2}

Relationship between $\mathrm{CD}_{8^{+}}$TLs (\% of total cells) and FVC (\% predicted), $\left(r_{s}=-0.67, p=0.01\right)$.

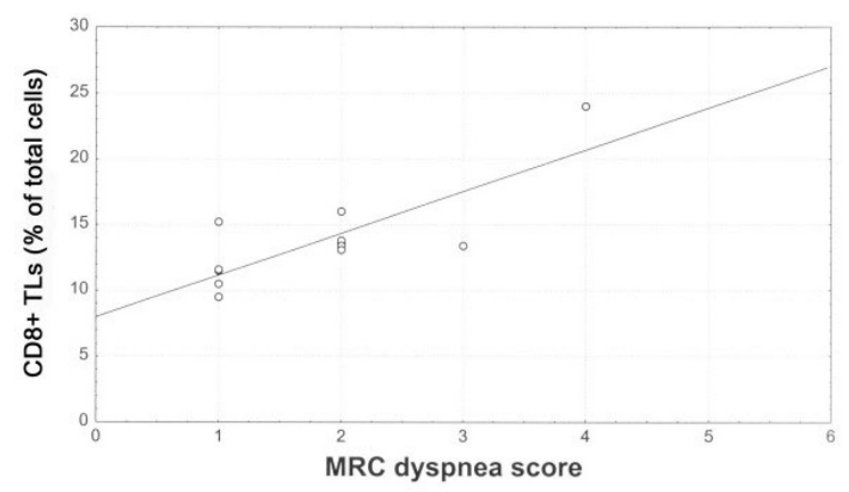

\section{Figure 4}

Relationship between $\mathrm{CD}_{8_{+}} \mathrm{TLs}$ (\% of total cells) and MRC dyspnea score, $\left(r_{s}=0.63, p=0.02\right)$.

most prominent and disabling symptom in these patients. This study shows that the type of the inflammatory infiltrate in lung tissue of patients with UIP/IPF was predominantly mononuclear, and that among the different inflammatory cells, $\mathrm{CD}_{8+}$ TLs correlated significantly with both functional [FVC, TLC, DLCO, $\mathrm{PaO}_{2}, \mathrm{P}(\mathrm{A}-\mathrm{a}) \mathrm{O}_{2}$ ] and clinical indices (the MRC chronic dyspnoea score) of the disease severity and extent studied and macrophages $\left(\mathrm{CD}_{68+}\right.$ cells) with some of the functional indices studied (FVC and $\mathrm{FEV}_{1}$ ).

Previous studies have shown that a patchy chronic interstitial inflammatory process coexists with an abnormal extracellular matrix deposition, foci of fibroblasts, and alveolar collapse in lung tissue of subjects with IPF
$[1,2,8,26]$. This inflammatory component in tissue specimens appeared to consist primarily of mononuclear cells (macrophages, lymphocytes and plasma cells) while the presence of the other inflammatory cells such as neutrophils and eosinophils appeared less numerous $[5,8,26,27]$. Previous studies of immunohistochemical analysis including the TLs subpopulations of lung tissue in IPF $[5,8,28,29]$ and other interstitial pneumonias [30] have shown that the inflammatory process is mainly mononuclear, and that both $\mathrm{CD}_{4+}$ and $\mathrm{CD}_{8_{+}}$TLs were well represented and diffusely distributed in the interstitium, with an additional component of the $\mathrm{CD}_{4+}$ TLs observed inside lymphoid follicles. Our findings do not contrast these observations.

Few studies have attempted to evaluate the structure-function relationship in IPF, and their findings are not always in agreement [31-35]. The selection of patients and the different methodologies might, at least in part, explain discrepancies. Our findings come into agreement with the studies by Fulmer and coworkers [31] and Chinet and coworkers [35] who found significant correlations between the degree of inflammation and lung volumes and some index of gas exchange. Gaensler and Carrington [34] also reported correlations between physiological indices and an estimate of functional impairment from histology (designated by them as pathological severity) in a large but mixed population (502 patients) with "interstitial lung disorders" including 64 patients with UIP. However, comparisons with previous studies are not always possible for the following reasons. First, we used a different methodology than the above-cited works. This is the first study attempted to correlate cell counts including TLs subpopulations in tissue biopsies with clinical and physiological parameters. This should be in relation to the fact that reliable cell counts were not feasible with the past technologies. Second, older studies might have included a mixed population of patients with UIP/IPF, patients with non-specific interstitial pneumonia and patients with pulmonary fibrosis associated with collagen vascular disorders since there were not defined strict criteria for these entities, by that time [36]. Finally, the patients' selection and the effect of previous treatment might have influenced the results.

Inflammatory cells including subpopulations of TLs have been also studied in IPF by bronchoalveolar lavage (BAL) [4] and many of the conclusions regarding the role of inflammation in interstitial lung disorders have been drawn from these studies. The possible role of lymphocytes in the pathogenesis of IPF traditionally received little investigation since increase in their number is an uncommon finding in BAL samples. Hence, early BAL studies have driven attention into neutrophils as well as macrophages. However, evidence from animal models 
appears to suggest that lymphocytes do play a role in fibrosis [4]. Furthermore, studies on BAL lymphocytes have shown that $\mathrm{CD}_{8+}$ TLs are prominent in BAL in IPF [36] and may also be associated with a worse prognosis [37]. T lymphocytes and their phenotypic and functional characteristics have been more extensively studied in scleroderma fibrosis [38-43]. IPF and scleroderma fibrosis are two fibroses with different prognoses [41]. This might be related to the fact that most patients with scleroderma develop a less aggressive form of fibrosing interstitial pneumonia, the non-specific interstitial pneumonia (NSIP) [42]. Indeed, studies that compared the prognosis of patients with "idiopathic" NSIP to that of patients with usual interstitial pneumonia type/IPF have clearly shown that the former present a far better prognosis than the latter [43]. Recent studies with BAL in scleroderma patients have shown that a subset of them, who present more than $15 \%$ lymphocytes in BAL [38], or have activated, longlived $\mathrm{CD}_{8+}$ T cells [40], or produce type 2 cytokines (IL-4 and IL-5) by the $\mathrm{CD}_{8+}$ TLs [39], present a more aggressive form of interstitial pneumonia. Hence, TLs and in particular the $\mathrm{CD}_{8+}$ subset may be associated with progressive fibrosis in scleroderma resembling more patients with IPF.

Notwithstanding correlations do not imply direct causeeffect relationships, we think that the significant negative correlations observed in this group of patients with IPF between $\mathrm{CD}_{8+}$ TLs and functional indices and the positive correlation observed between the same cells and clinical indices estimating the disease severity as well as the correlation between $\mathrm{CD}_{68+}$ cells with $\mathrm{FVC}$ and $\mathrm{FEV}_{1}$ might suggest a potential pathophysiologic relevance for mononuclear cells and especially $\mathrm{CD}_{8+}$ TLs in the pathogenesis of pulmonary fibrosis. However, the mechanisms related to these correlations and the relationship of inflammatory and immune parameters to structural changes in the lung parenchyma still remain unknown and further studies are needed for their clarification.

The increase in $\mathrm{CD}_{8+}$ TLs observed in lung surgical biopsies in patients with IPF appears intriguing. Classically, the major role of $\mathrm{CD}_{8+}$ TLs in the inflammatory response has been considered the rapid resolution of viral infections [44]. It has also become evident that $\mathrm{CD}_{8+}$ TLs may contribute to lung injury $[45,46]$. Viruses have been implicated in the pathogenesis of IPF, and a higher incidence of viral infections (Ebstein Barr Virus, influenza, cytomegalovirus, and possibly Hepatitis $\mathrm{C}$ virus) has been reported in these patients [19]. Recently, it has been hypothesized that in patients with IPF an excessive recruitment of $\mathrm{CD}_{8+}$ TLs may occur in response to recurrent or persistent viral infections, and this excessive response may play a role for the development of lung damage [47]. The above hypothesis has received some experimental confirmation by the studies of Enelow and coworkers [47] and Small and coworkers [48] who have shown that antigen-specific $\mathrm{CD}_{8+} \mathrm{T}$ cell recognition of an alveolar epithelial "autoantigen" is sufficient to trigger an inflammatory cascade that results in the histological and physiological manifestations of interstitial pneumonia. $\mathrm{CD}_{8+}$ TLs can differentiate into cells that make IFN- $\gamma$ but no IL-4 (Tc1 cells) promoting attenuation of fibrosis and cells that make IL-4 but not IFN- $\gamma$ (Tc2 cells) leading to exuberant fibrosis [49]. Though further studies are necessary to address the specific role of the Tc 2 cells in pulmonary fibrosis, some data such as the upregulation of genes encoding immunoglobulins and extracellular matrix proteins in IPF lung tissue [50] appear to suggest that the predominance of type- 2 immune response in IPF [51] is what drives the process in profibrogenic direction.

\section{Conclusion}

We found that the type of the inflammatory cell infiltrate in surgical biopsies of patients with UIP/IPF was predominantly mononuclear. Among the different inflammatory cells revealed by immunohistochemistry, the $\mathrm{CD}_{8+} \mathrm{TLs}$ correlated significantly with both functional [FVC, TLC, DLCO, $\mathrm{PaO}_{2}, \mathrm{P}(\mathrm{A}-\mathrm{a}) \mathrm{O}_{2}$ ] and clinical indices (the MRC chronic dyspnoea score) of disease severity and extent studied and the $\mathrm{CD}_{68+}$ cells with FVC and $\mathrm{FEV}_{1}$. These data might suggest a potential role for mononuclear cells and especially $\mathrm{CD}_{8+}$ TLs in the pathogenesis of pulmonary fibrosis. However, because of the relatively small size of the population studied, further studies are needed to support our findings.

\section{Competing interests}

The author(s) declare that they have no competing interests.

\section{Authors' contributions}

ZD participated in the design of the study and collection of the clinical data, performed the statistical analysis and drafted the manuscript. PK carried out the histology and the immunohistochemical analysis and revised the article. GK participated in the collection of the data and helped to draft the manuscript. MD helped in biopsy evaluation, diagnosis and analysis. AK participated in tissue collection and data analysis. MK participated in data analysis. JM-E helped in the interpretatiuon of the data and revised the article. CR participated in the interpretation of the data and revised the article. SP conceived of the study, participated in its design and coordination and helped to draft the manuscript. All authors read and approved the final manuscript.

\section{Acknowledgements}

Supported by the "Thorax" Foundation, Athens, Greece. 


\section{References}

I. Katzenstein A, Zisman AD, Litzky AL, Nguyen TB, Kotloff MR: Usual interstitial pneumonia. Histologic study of biopsy and explant specimens. Am J Surg Pathol 2002, 26: I 567-I577.

2. Flaherty KR, Travis WD, Colby TV, Toews BG, Kazerooni AE, Gross HB, Jain A, Strawderman LR III, Flint A, Lynch PJ III, Martinez JF: Histopathologic variability in usual and nonspecific interstitial pneumonias. Am J Respir Crit Care Med 2001, I 64: I722-1727.

3. Gross TJ, Hunninghake GW: Idiopathic pulmonary fibrosis. $N$ Engl J Med 200I, 345:517-525.

4. Riches WHD, Worthen GS, Augustin A, Lapadat R, Chan DE: Inflammation in the pathogenesis of interstitial lung disease. In Interstitial Lung Disease Edited by: Schwartz JM, King ET Jr. Hamilton London BC Decker; 2003: I 87-220.

5. Kradin RL, Divertie MB, Colvin RB, Ramirez J, Ryu J, Carpenter HA, Bhan AK: Usual interstitial pneumonitis is a T-cell alveolitis. Clin Immunol Immunopathol 1986, 40:224-235.

6. Crystal RG, Fulmer JD, Roberts WC, Moss ML, Line BR, Reynolds HY: Idiopathic pulmonary fibrosis. Clinical, histologic, radiographic, physiologic, scintigraphic, cytologic and biochemical aspects. Ann Intern Med 1976, 85:769-788.

7. Hunninghake GW, Kawanami O, Ferrans VJ, Young RC, Roberts WC Crystal RG: Characterization of the inflammatory and immune effector cells in the lung parenchyma of patients interstitial lung disease. Am Rev Respir Dis I98I, I 23:407-4I2.

8. Campell DA, Poulter LW, Janossy G, du Bois RM: Immunohistological analysis of lung tissue from patients with cryptogenic fibrosing alveolitis suggesting local expression of immune hypersensitivity. Thorax 1985, 40:405-4II.

9. Haslam PL, Turton CW, Lukoszek A, Salsbury AJ, Dewar A, Collins JV, Turner-Warwick M: Bronchoalveolar lavage fluid cell counts in cryptogenic fibrosing alveolitis and their relation to therapy. Thorax 1980, 35:328-339.

10. Reynolds HY, Fulmer JD, Kazmierowski JA, Roberst WC, Frank MM, Crystal RG: Analysis of cellular and protein content of broncho-alveolar lavage fluid from patients with idiopathic pulmonary fibrosis and chronic hypersensitivity pneumonitis. J Clin Invest 1977, 59:165-175.

II. Peterson MW, Monick M, Hunninghake GW: Prognostic role of eosinophils in pulmonary fibrosis. Chest 1987, 92:5I-56.

12. Lynch JP 3rd, Standiford TJ, Rolfe MW, Kunkel SL, Strieter RM: Neutrophilic alveolitis in idiopathic pulmonary fibrosis. The role of interleukin-8. Am Rev Respir Dis 1992, I 45:|433-|439.

13. Selman M, King TE Jr, Pardo A: Idiopathic pulmonary fibrosis: prevailing and evolving hypotheses about its pathogenesis and implications therapy. Ann Intern Med 200I, I34:I36-I5I.

14. Piguet PF, Collart MA, Grau GE, Kapanci Y, Vassali P: Tumor necrosis factor/cachectin plays a key role in bleomycin induced pneumopathy and fibrosis. I Exp Med 1989, I 70:655-663.

15. $\mathrm{Hu} \mathrm{H}$, Stein-Streilein J: Hapten-immune pulmonary interstitial fibrosis (HIPIF) in mices requires both $C D_{4+}$ and $C D_{8+}$ T-lymphocytes. J Leukocyte Biol 1993, 54:4|4-422.

16. Furuie H, Yamasaki H, Suga M, Ando M: Altered accessory cell function of alveolar macrophages: a possible mechanism for induction of Th 2 secretory profile in idiopathic pulmonary fibrosis. Eur Respir J 1997, 10:787-794.

17. Hancock A, Armstrong L, Gama R, Millar A: Production of interleukin 13 by alveolar macrophages from normal and fibrotic lung. Am J Respir Cell Mol Biol 1998, I 8:60-65.

18. Romagnani S: ThI/Th2 cells. Inflamm Bowel Dis 1999, 5:285-294.

19. American Thoracic Society: Idiopathic pulmonary fibrosis: diagnosis and treatment. International consensus statement. Am J Respir Crit Care Med 2000, I 6 I:646-664.

20. Quanjer PhH, Tammeling GJ, Cotes JE, Pedersen OF, Peslin R, Yernault J-C: Lung volumes and forced ventilatory flows. Report working party, Standardization of lung function tests, European Community for steel and coal. Official Statement of the European respiratory Society. Eur Respir J 1993:5-40.

21. Cotes JE, Chinn DJ, Quanjer PhH, Roca J, Yernault J-C: Standardization of the measurement of transfer factor (Diffusing Capacity). Report working party, Standardization of lung function tests, European Community for steel and coal. Official Statement of the European respiratory Society. Eur Respir J 1993:4I-52.

22. Eltayara L, Becklake MR, Volta CA, Milic-Emili J: Relationship between chronic dyspnea and expiratory flow limitation in patients with chronic obstructive pulmonary disease. Am J Respir Crit Care Med 1996, I 54: I726-I734.

23. Brugal T, Arnorssen R, Bengtsson A, Wilander E: A double scanning micromorphometer for image analysis: hardware, software and biomedical applications. J Histochem Cytochem 1979, 27:| $44-152$

24. Charpin C, Martin P, Jacquemin J, Jacquemier J, Lavaut MN, PourreauSchneider N, Toga M: Estrogen receptor immunocytochemical assay (ER-ICA): Computerized image analysis system, immunoelectron microscopy and comparisons with estradiol binding assays in 115 breast assays in 115 breast carcinomas. Cancer Res 1986:427|-4277.

25. Costes V, Marty-Ane C, Picot MC, Serre I, Pujol J-L, Mary H, Baldet $P$ : Typical and Atypical Bronchopulmonary Carcinoid Tumors: A Clinicopathologic and Ki-67-Labeling Study. Hum Pathol 1995, 26:740-745.

26. White SR, Lazar HM, Thannichal JV: Pathogenetic mechanisms in usual interstitial pneumonia/idiopathic pulmonary fibrosis. J Pathol 2003, 20 I:343-354.

27. Haslam LP, Turton WGC, Heard B, Lukoszek A, Collins VJ, Slasbury $A$, Turner-Warwick : Bronchoalveolar lavage in pulmonary fibrosis: comparison of cells obtained with lung biopsy and clinical features. Thorax 1980, 35:9-18.

28. Haslam LP: Evaluation of alveolitis by studies of lung biopsies. Lung 1990:984-992.

29. Paradis LI, Dauber HJ, Rabin SB: Lymphocyte phenotypes in bronchoalveolar lavage and lung biopsies in sarcoidosis and idiopathic pulmonary fibrosis. Am Rev Respir Dis 1986, I 33:855-860.

30. Yamadori I, Fujiata J, Kajitani H, Tokuda M, Yang Y, Ohtsuki Y, Yoshinouchi $T$, Kamei $T$, Ishida $T$ : Lymphocytic subsets in lung tisuue of non-specific interstitial pneumonia and pulmonary fibrosis associated with collagen vascular disorders: correlation with CD4/CD8 ratio in bronchoalveolar lavage. Lung 2000, | 78:36|-370.

31. Fulmer JD, Roberts WC, Von Gal R, Crystal RG: Morphologicphysiologic correlates of the severity of fibrosis and degree of cellular infiltration in idiopathic pulmonary fibrosis. J Clin Invest 1979, 63:665-676.

32. Green GM, Graham GB, Hanson JS, Gump DW, Phillips CA, Brody AR, Sylvester DW, Landis JN, Davis GS, Craighead JE: Correlate studies of interstitial pulmonary disease. Chest 1976:263.

33. Gaensler EA, Carrington CB, Coutu RE, FitzGerald MX: Radiologicphysiologic-pathologic correlations in interstitial pneumonias. Prog Respir Res 1975, 8:223-24I.

34. Gaensler EA, Carrington CB: Open lung biopsy for chronic diffuse infiltrative lung disease: clinical, roentgenographic and physiologic correlations in $\mathbf{5 0 2}$ patients. Ann Thorac Surg 1980, 30:4 I I-426.

35. Chinet T, Jaubert F, Dusser D, Danel C, Chretien J, Huchon JG: Effects of inflammation and fibrosis on pulmonary function in diffuse lung fibrosis. Thorax 1990, 45:675-768.

36. Groen H, Hamstra M, Aalbert R, Van Der Mark WT, Koëter HG Postma SD: Clinical evaluation of lymphocyte sub-populations and oxygen radical production in sarcoidosis and idiopathic pulmonary fibrosis. Respir Med 1994, 88:55-64.

37. Fireman E, Vardinon N, Burke M, Soizer S, Levin S, Endler A, Stav D, Topilsky M, Mann A, Schwarz S, Greif J: Predictive value of response to treatment of T-lymhocyte subpopulations in idiopathic pulmonary fibrosis. Eur Respir J I998, I I:706-7 I I.

38. Behr J, Vogelmeier C, Beinert T, Meurer M, Krombach F, Konig G, Fruhmann $G$ : Bronchoalveolar lavage for evaluation and management of scleroderma disease of the lung. Am J Respir Crit Care Med 1996, I 54:400-6.

39. Atamas SP, Yurovsky VV, Wise R, Wigley FM, Goter Robinson CJ, Henry P, Alms WJ, White B: Production of type 2 cytokines by CD8+ lung cells is associated with greater decline in pulmonary function in patients with systemic sclerosis. Arthritis Rheum 1999, 42: I 168-78.

40. Luzina IG, Atamas SP, Wise R, Wigley FM, Choi J, Xiao HQ, White B: Occurrence of an activated, profibrotic pattern of gene expression in lung CD8+ $T$ cells from scleroderma patients. Arthritis Rheum 2003, 48:2262-74.

4I. Papiris SA, Vlachoyiannopoulos PG, Maniati MA, Karakostas KX, Constantopoulos $\mathrm{SH}$, Moutsopoulos $\mathrm{HH}$ : Idiopathic pulmonary fibrosis and pulmonary fibrosis in diffuse systemic sclerosis: 
two fibroses with different prognoses. Respiration 1997, 64:8I-5.

42. Flaherty KR, Colby TV, Travis WD, Toews GB, Mumford J, Murray S, Thannickal VJ, Kazerooni EA, Gross BH, Lynch JP 3rd, Martinez FJ: Fibroblastic foci in usual interstitial pneumonia: idiopathic versus collagen vascular disease. Am J Respir Crit Care Med 2003, 167:|4|0-5

43. Daniil ZD, Gilchrist FC, Nicholson AG, Hansell DM, Harris J, Colby TV, du Bois RM: A histologic pattern of nonspecific interstitial pneumonia is associated with a better prognosis than usual interstitial pneumonia in patients with cryptogenic fibrosing alveolitis. Am J Respir Crit Care Med 1999, 160:899-905.

44. Ramsay A, Ruby J, Ramshaw I: A case for cytokine as effector molecules in the resolution of virus infection. Immunol Today 1993, I4:155-157.

45. Alwan WH, Kozlowska WJ, Opensaw PJ: Distinct types of lung disease caused by functional subsets of antiviral T cells. J Exp Med 1994, 179:81-89.

46. Guidotti LG, Chisari FV: To kill or to cure: options in host defense against viral infection. Curr Opin Immunol 1996, 8:478-483.

47. Enelow RI, Mohammed AZ, Stoler MH, Ning Liu A, Young JS, Lou Y$\mathrm{H}$ : Structural and functional consequences of alveolar cell recognition by $\mathrm{CD}^{+} \mathrm{T}$ Lymphocytes in experimental lung disease. J Clin Invest 1998, 102:1653-166I.

48. Small BA, Dressel SA, Lawrence CW, Drake DR III, Stoler MH, Enelow RI, Braciale TJ: CD8+ $\mathbf{T}$ Cell-mediated Injury In Vivo Progresses in the Absence of Effector T Cells. J Exp Med 200I, 194: | 835-1846.

49. Croft M, Carter L, Swain SL, Dutton RWL: Generation of polarized antigen-specific CD8 effector populations: reciprocal action of interleukin (IL)-4 and IL- 12 in promoting type 2 versus type I cytokine profiles. J Exp Med 1994, I 80: I7I 5-I728.

50. Zuo F, Kaminski N, Eugui E, Allard J, Yakhini Z, Ben-Dor A, Lollini L, Morris D, Kim Y, DeLustro B, Sheppard D, Pardo A, Selman M, Heller RA: Gene expression analysis reveals matrilysin as a key regulator of pulmonary fibrosis in mice and humans. Proc Natl Acad Sci USA 2002, 99:6292-6297.

51. Strieter RM, Keane MP: Innate immunity dictates cytokine polarization relevant to the development of pulmonary fibrosis. J Clin Invest 2004, I I 4: I65-168.

Publish with Bio Med Central and every scientist can read your work free of charge

"BioMed Central will be the most significant development for disseminating the results of biomedical research in our lifetime. "

Sir Paul Nurse, Cancer Research UK

Your research papers will be:

- available free of charge to the entire biomedical community

- peer reviewed and published immediately upon acceptance

- cited in PubMed and archived on PubMed Central

- yours - you keep the copyright

Submit your manuscript here:

http://www.biomedcentral.com/info/publishing_adv.asp
BiolMedcentral 